\title{
Race, Archival Silences, and a Black Footballer between the Wars
}

In 1931, Eddie Parris became the first person of colour to represent Wales at football. Earlier that same year, The Welsh Outlook received a letter entitled 'The Colour Problem in Wales'. It claimed that the law courts witnessed a daily procession of foreigners charged with 'razor slashing and assaults on the police, drunkenness and disorderliness, gambling and running or frequenting disorderly houses, landing without passports, tobacco and dope smuggling, stealing and stabbing.' It went on:

Half-caste children, the result of illicit and legal unions, are multiplying with alarming rapidity, and according to the Chief Constable's estimate there are now upwards of five hundred half-caste children in the infamous "Tiger Bay" and "Nigger Town" districts, children for whom there is little or no prospect of employment on account of their demi-monde characteristics, either on land or sea, children shunned and despised by thoroughbred whites, yellows and blacks. ${ }^{1}$

Britain was thus a society shot through with racist attitudes but also one where a man of mixed racial heritage could represent his country in an important cultural sphere.

The depth of racial prejudices in early twentieth-century Britain have long been recognized by historians. Framed by a colonial context that used ideas of racial hierarchies to justify the exploitation of others, people of colour were widely looked down upon as mentally and culturally inferior. There was a reluctance for personal contact and an unwritten colour bar in many British restaurants, hotels and jobs. On occasions, people of colour were the victims of significant violence. ${ }^{1}$ However, historians have also pointed to the danger of reducing people of colour to victims of white racism and of making histories of race about white attitudes rather than black experiences. ${ }^{1}$ Robinson has demonstrated how ayahs who came to Britain with their employers were not just victims of colonial systems but a skilled and assertive labour force that levered economic opportunities for itself. ${ }^{1}$ Matera and others have shown how, in response to racisms, a vibrant intellectual black culture developed in interwar London that saw itself as part of a global pan-Africanism. ${ }^{1}$ Similarly, Balachandran

1 'The Colour Problem in Wales', The Welsh Outlook, 18:5 (1931), p. 137.

${ }^{1}$ On discrimination in the workplace: Laura Tabili, 'We ask for British Justice': Workers and Racial Difference in Late Imperial Britain (Ithica, 1994) and Ron Ramdin, The Making of the Black Working Class in Britain (Aldershot, 1987). For white attitudes: Tony Kushner, We Europeans? MassObservation, 'Race' and British Identity in the Twentieth Century (Aldershot, 2004); Simon Jenkins, 'Aliens and predators: miscegenation, prostitution and racial identities in Cardiff, 1937-47', Cultural and Social History, 11:4 (2014), 575-96; Mark Christian, 'The Fletcher Report 1930: a historical case study of contested black mixed heritage Britishness', Journal of Historical Sociology, 21:2/3 (2008), 213-41; Richard C. Thurlow, 'Satan and Sambo: the image of the immigrant in English racial populist thought since the First World War', in Kenneth Lunn (ed), Hosts, Immigrants and Minorities: Historical Responses to Newcomers in British Society 1870-1914 (Folkestone, 1980), 39-63. On the role of Empire in shaping prejudice: Bill Schwarz, The White Man's World (Oxford, 2011). For racial violence: Jacqueline Jenkinson, Black 1919: Riots, Racism and Resistance in Imperial Britain (Liverpool, 2009).

${ }^{1}$ For a pioneering study that foregrounds black experiences rather than white attitudes after the war see Kennetta Hammond Perry, London is the Place for Me: Black Britons and the Politics of Race (Oxford, 2016).

${ }^{1}$ Olivia Robinson, 'Travelling Ayahs of the Nineteenth and Twentieth Centuries: Global Networks and Mobilization of Agency', History Workshop Journal, 86, (2018), 44-66.

${ }^{1}$ Marc Matera, Black London: The Imperial Metropolis and Decolonization in the Twentieth Century (Oakland, 2015). Susan Pennybacker, From Scottsboro to Munich: Race and Political Cultures in 
has argued there was an 'embattled subaltern cosmopolitan' working-class society and that attending 'to these lives, [and] their stories' pushes the historiography away from seeing people of colour in Britain as victims and onto their methods of resistance and negotiation. ${ }^{1}$

Yet many such stories have not been explored and much of the history of African and Caribbean people in Britain, remains, as Adi wrote in 2019, 'a hidden history to a large extent'. ${ }^{1}$ This might owe something to how historians have worked. Habib has argued that assumptions about the whiteness of early modern England owe much to historians simply not looking for black people in the archival records. ${ }^{1}$ As Habib's work showed, the fleeting and fragmentary nature of many references necessitates laborious research across many different archives. It can also require archives to be read with more emphasis on who they were about rather than who they were written by. Wills has described her research into the history of post-1945 migration from the perspective of migrants as a 'process of excavation' from a diverse range of sources from across the globe which needed to be read from the 'inside out'. 1

When it comes to studying black working-class experiences earlier in the century, this is easier said than done. ${ }^{1}$ Sources about the black working class as a category exist, and have formed the basis of the histories of their racial exclusion, but too often the archival records seem silent when it comes to individuals and the details of their lives. Of course, the historical record is scant on most white working-class figures too but with anyone of colour the situation is more complicated. The relatively small number of people of colour in early twentieth-century Britain means that first-hand black working-class accounts are very rare. Court reports do sometimes offer black working-class testimony but these are always mediated by white court reporters. ${ }^{1}$ Even identifying who was black is not easy because so many official sources, including the census and birth and death records, did not record racial details. When someone's colour is mentioned in public sources such as newspapers, it is often when they were being prosecuted or blamed for something, but even court-case reports do not always record the fact that a victim or accused was black. Bressey has pointed to the irony of historians being 'hampered' by not just the 'absence of colour' in archives but also the 'ideas of race and racism' that they seek to explore. ${ }^{1}$ If archives do not capture someone's race then nor do they record any racism that person might have experienced. Even where people of colour can be identified, how race affected their daily lives is often not reported unless it ended in violence or involved some public white campaign against their employment. The

1930s Britain (Princeton, 2009). Minkah Makalani, In the Cause of Freedom: Radical Black Internationalism from Harlem to London, 1917-1939 (Chapel Hill, 2011). Bill Schwarz (ed), West Indian Intellectuals in Britain (Manchester, 2003).

${ }^{1}$ G. Balachandran, 'Subaltern cosmopolitanism, racial governance and multiculturalism: Britain, c. 1900-45', Social History, 39:4 (2014), 528-46, quote from p. 546.

${ }^{1}$ Hakim Adi,' Introduction', in Hakim Adi (ed), Black British History: New Perspectives (London, 2019), p. 2.

${ }^{1}$ Imitiaz Habib, Black Lives in the English Archives, 1500-1677: Imprints of the Invisible (London, 2008), introduction.

${ }^{1}$ Clair Wills, Lovers and Strangers: An Immigrant History of Post-War Britain (London, 2018), p. xix

${ }^{1}$ For a beginning on working-class black history that notes the difficulty of getting beyond sketchy details see Caroline Bressey, 'Looking for work: the black presence in Britain, 1860-1920', Immigrants and Minorities, 28: 2-3 (2010), 164-82.

${ }^{1}$ For a study of the perspective of Indian sailors using reports of court cases see James Frey, 'Lascars, the Thames Police Court and the Old Bailey: crime on the high seas and the London courts, 1852-8', Journal for Maritime Research, 16 (2014), 196-211.

${ }^{1}$ Caroline Bressey, 'Invisible presence: the whitening of the black community in the historical imagination of British archives', Archivaria, 61:1 (2006), 47-61, quote from p. 61. 
more mundane racial experiences of working-class people of colour are often simply invisible in the historical record.

The absence of racism in some archival records does not mean that Britain was not a racialized society or that discrimination was not commonplace but it does at least encourage a more nuanced view that steps beyond racism being the only lens through which to look at the black experience. Prejudice existed and structured many black experiences but class, gender, personality, place and occupation also played their parts in shaping not just how black men and women were treated but their reactions to their treatment too. Such intersectional perspectives matter because, as Tabili points out, 'the vast majority of overseas migrants lived in households with British-born people, exposed to local custom and culture in the intimate realm of private life'. ${ }^{1}$ Employing census data for people not born in Britain and those with non-Christian names, she and Holland have demonstrated the extent of marriage and other domestic interactions between working-class natives and migrants in South Shields and Yorkshire. Such a method does not capture everyone of colour, and, because of naming habits, it is easier for those who were Asian rather than black, but it does avoid stressing racial barriers over dialogues and of isolating 'migrants analytically from British society and history'. ${ }^{1}$ Thus while census and other official records such as birth, marriage and death certificates do not record racial details they can still allow working-class people of colour to be thought of in terms of their family life and occupations. Even who they lived next door to can become part of their story. They can be discussed as part of communities rather than merely victims or resisters of racism.

Listening out for the fleeting archival sounds left by black lives is made much easier by the digital revolution. Laite's research on sex workers has shown how digital resources allow specific individuals to be quickly located across multiple archives, fleshing out the detail of obscure lives in ways that would otherwise have been impossible. ${ }^{1}$ This is also true for people of colour. Digital genealogy resources can further help bring some noise to the silence of archives by putting the researcher in touch with descendants of a subject. This opens up the possibility of photographs in private hands and first and second-hand memories. Keyword searches, meanwhile, bring to light the infrequent racial comments scattered across the press and other archives and the ways race could be employed in perhaps surprising ways. Bressey, a pioneer in this, has used keyword searching to identify how race was employed in domestic service press advertisements by both workers and employers. Yet the digital archive is still silent on why people mentioned their colour or why some employers wanted black servants. ${ }^{1}$ This can only be explored through contextualization and a degree of conjecture. Moreover, digitally searching for racial terms inevitably leads the historian to focus on them rather than the interactions where race was less relevant or even invisible. Thus searching for an black individual in the archives can be an alternative way to assess the dynamics of race for working-class people of colour. It can be a way of assessing both the significance and insignificance of race.

Sport was one of the few forums where black individuals had any public profile that would leave an archival trace. This article thus explores the life of Welsh footballer Eddie Parris in order to investigate the working-class black experience in interwar Britain and more generally the long history of black players within the game. The public accolades Parris

\footnotetext{
${ }^{1}$ Laura Tabili, Global Migrants, Local Culture: Natives and Newcomers in Provincial England, 1841-1939 (Basingstoke, 2011), p. 9.

${ }^{1}$ Tabili, Global Migrants, p. 7. David Holland, 'The social networks of South Asian migrants in the Sheffield area during the early twentieth century', Past and Present, 236 (2017), 243-79.

${ }^{1}$ Julia Laite, 'The Emmet's Inch: small history in a digital age', Journal of Social History, shaa018 (2020).

${ }^{1}$ Bressey, 'Looking for work'.
} 
received demonstrate how black working-class men could forge successful careers and win white respect. Genealogy records have allowed some picture of his private life to be built up, demonstrating how black lives were about so much more than just negotiating and overcoming prejudice. Yet archival and methodological challenges remain. Parris was often framed as different through constant press references to his colour but explicit evidence of racism towards him is absent raising the question of how much prejudice he faced. The archives are also silent on how he regarded his own racial position; Parris was always someone who was represented in the press rather than spoke through it. Thus contextualization and inference remain important in interrogating even the lives of black working-class individuals who had a public profile. Ideas of racial superiority were so embedded in British society that it is inconceivable that Parris did not face prejudice and spend much of his life negotiating it. This might be conjecture but the alternative is to allow the archival silence around racism eradicate acknowledgement of it.

This article thus confirms both the historiographies that centralize racism and those that argue for the importance of understanding 'mutual everyday or informal tolerance towards ethnic difference'. ${ }^{1}$ It acts as a reminder of the importance of thinking of people of colour in early twentieth-century Britain as actual individuals rather than just as the racialized category that contextualization inevitably foregrounds. Nonetheless, notions of racial difference were so pervasive that race can never have been irrelevant. The task for the historian is acknowledge and investigate the impact of these ideas without letting them push aside the actual people within them.

\section{The Parris family}

John Edward Parris was born at Ivy Cottage in the rural village of Pwllmeyric, just outside the small Welsh town of Chepstow, on 31 January 1911. His mother, Annie Clarke, was born in Leicester, while his father, also named John Edward Parris, was a telegraph wireman with the Post Office who had been born in Barbados. ${ }^{1}$ There is no record of when and why his father came to Britain but in the late nineteenth and early twentieth centuries there was largescale migration from the Caribbean in response to falling wages and other local economic problems. ${ }^{1}$ It was not unusual for migrants to move inland from the ports they arrived at in search of work. ${ }^{1}$ By the time of his marriage in 1909, Parris senior was living in Tutshill, a village near Chepstow but on the English side of the border.

Parris senior's wife was Annie Clarke, a 24-year-old labourer's daughter with a complicated history. At sixteen she had had a son out of wedlock who was not brought up by her. In 1904, aged 21, she had married a 69-year-old. He soon died and in April 1908 she had an illegitimate daughter named Mabel. Eighteen months later she married Parris. For any white woman to marry a black man would not have been an easy decision since interracial sex was widely disapproved of. Yet there were working-class women willing to challenge such prejudices. ${ }^{1}$ Love was one reason but a desire for respectability and security could be another. It maybe that by marrying Parris, Annie gained this at a time when her options were

\footnotetext{
${ }^{1}$ Holland, 'Social networks', p. 278.

${ }^{1}$ Dates of birth and the like in this paper were located through genealogical research on the Ancestry.co.uk and Findmypast.com websites.

${ }^{1}$ Perry, London is the Place for Me, p. 63. He may have come via Canada which is wrongly listed as his birthplace on the 1911 census, an example of how archives can be flawed as well as silent.

${ }^{1}$ Tabili, Global Migrants, Local Culture.

${ }^{1}$ Matera, Black London, ch. 5. Lucy Bland, 'White women and men of colour: miscegenation fears in Britain after the Great War', Gender and History, 17:1 (2005), 29-61, p. 52.
} 
limited. Certainly, some contemporaries thought that one reason for white women being in a relationship with black men was a desire for security after having an illegitimate child by a white man who refused to marry them. ${ }^{1}$ But Parris was a skilled workman and thus someone of status; marrying him would thus not have been simply an act of desperation. Moreover, the marriage lasted the rest of their lives.

In September 1916, Parris senior joined the Royal Engineers as a signaller, going on to serve in Salonica. ${ }^{1}$ His military records show that the family had now moved to Newport and included a third child. Beyond these sketchy details, it is impossible to discern much about the life of the Parris family. For those who knew them, they were living personalities but for the historian a century later, they are little more than names in censuses, military records and birth, marriage and death certificates. And not one of those sources record the fact that the father was black and his children of mixed heritage. Only his son's career as a footballer has brought that to light.

\section{Race and racism in British society}

By the time Parris senior was discharged from the army in August 1919, the family had moved to Chepstow. When they moved is unclear but in June 1919 rioting broke out in the docks area of Newport where the family had been living. The readjustment of the shipping industry to peacetime conditions caused unemployment amongst both black and white workers, with tensions further exacerbated by a housing shortage. Fighting broke out after a black man had allegedly insulted a white woman. Trouble spread, shots were fired, black men's windows were smashed, and two houses were emptied and their furniture burnt. A crowd shouted racial abuse and one woman was told she should be burned because she was married to a black man. ${ }^{1}$ There were similar riots that summer in Cardiff, Barry, and other seaports, resulting in five deaths and at least 250 arrests. In the riots' aftermath there was debate in the Newport press about race relations, with one letter suggesting a system of segregation where black people were forced to sit at the rear of trams and any black men and white women seen together immediately arrested. ${ }^{1}$ If Eddie Parris, then eight years old, was living with his mother and siblings in the vicinity of the Newport riots, then it is hardly surprising that they quickly moved away. It is not impossible that the family were even caught up in the events. But even if they had already moved away, the news would have reached them and a white woman married to a black man surely must have been affected by what had happened to other people like her in a neighbourhood where she had recently lived.

The hostile prejudice revealed in the riots was generally frowned upon in interwar British society but a belief in racial equality was rare. Indeed, it can be argued that British culture was inherently racist. The Empire was legitimized by a racial hierarchy: the white man thought he was taking civilization and progress to the world, and its successes reinforced the idea of white superiority. At a less abstract level, with varying degrees of subtlety, black men were subject to ridicule as inferior, savage and uncivilized in magazines, films, popular books and plays. There were also widespread beliefs that black people smelt and were akin to children in their general development. So engrained were such feelings that even those who disapproved vehemently of colour prejudice could still feel a strong sense of racial difference. ${ }^{1}$ Indeed, the belief that colour prejudice was wrong could be rooted in a paternal

\footnotetext{
${ }^{1}$ Christian, 'Fletcher Report', pp. 227-8.

${ }^{1}$ John Edward Parris, British Army WWI Service Records, 1914-1920 (via Ancestry.com).

${ }^{1}$ The Times, 17 June 1919.

${ }^{1}$ Jenkinson, Black 1919, p. 108.

${ }^{1}$ Kushner, We Europeans?, pp.113-5, 121.
} 
sense of duty to look after those less fortunate. A 1948 study argued: 'In the abstract sense ... English people on the whole are favourably disposed and sympathetic towards the coloured man. They believe as keenly in the idea of his being given 'a square deal' as in that of democracy'. But it also found 'a wide variety of prejudices against coloured persons' and an unwillingness for social contact. ${ }^{1}$ Black Britons and visitors could consequently find themselves barred from hotels, boarding houses and restaurants. They frequently experienced unemployment and discrimination at the hands of the police. ${ }^{1}$ They even learned not to offer a handshake because of how often it would be ignored. ${ }^{1}$

This unofficial colour bar was probably strongest in places like London and Cardiff that had significant and longstanding black populations. In Cardiff, just fifteen miles from Newport, the interwar black population of around 3,000, was confined by the availability of accommodation and employment to the docks area. The result was that the city was racially segregated and demarcated. Yet within the docks area, day-to-day interactions between races were relatively harmonious. ${ }^{1}$ Outside such ports, many proprietors probably never needed to think about whether they wanted black custom because Britain was overwhelmingly white. In 1911, 450 residents of Parris' home county of Monmouthshire had been born in British colonies, of whom just 39 were born in the West Indies. ${ }^{1}$ How many of them were black is impossible to tell since the official record did not count. Nor was there any official record of the colour of those born in the UK, leaving historians to estimate the UK's 1945 black population as between 10,000 and 30,000. ${ }^{1}$ This meant most people in Britain did not have personal contact with anyone of colour and their racial attitudes owed more to their personal beliefs and the stereotypes of popular culture than from any first-hand experience. The result was when there was contact with those of a different colour people could be uncertain of how to behave or even rude or aggressive. ${ }^{1}$

Historians have begun to explore how black men and women responded to such attitudes but the evidential base has meant they have focussed on middle-class perspectives. Education levels mean it is unlikely that the kind of intellectual spaces that Matera has analysed in London - where black men were brought together by 'shared oppression and a commitment to black liberation', forging a common sense of a racial and African identity were open to black working-class individuals. ${ }^{1}$ Parris was furthered isolated by the fact that after his childhood, he did not live anywhere with a sizable black population and at times may have been the only person of colour in his immediate community. In this context, and that of confused and contradictory white attitudes, Parris probably grew up very aware of his colour, experiencing at least occasional outright hostility and probably more often uncertainty and patronising and aloof attitudes. In 1935 he married a white woman, Agnes Shaw, the

\footnotetext{
${ }^{1}$ K. L. Little, Negroes in Britain: A Study of Racial Relations in English Society (London, 1947), pp. 218-23, 226-7.

${ }^{1}$ Matera, Black London, p. 37. Ramdin, Making of the Black Working Class, p. 79.

${ }^{1}$ Learie Constantine, Colour Bar (London, 1954), p. 67.

${ }^{1}$ For a contemporary study of race in Cardiff see Little, Negroes in Britain. Oral histories of black people who lived in London between the wars also paint pictures of harmonious race relations. Stephen Bourne, Black in the British Frame: The Black Experience in British Film and Television (London, 2001), p. 39.

${ }^{1}$ Census of England and Wales, 1911, vol. IX: Birthplaces, Cd. 7017 (1913), p. 65.

${ }^{1}$ Perry, London is the Place for Me, p. 7.

${ }^{1}$ This was evident in the treatment of black GIs during the war and the fact that the government felt the need to offer advice on the matter to the public. Perry, London is the Place for Me, p. 103.

${ }^{1}$ Matera, Black London, p. 221.
} 
daughter of a Rotherham miner who he presumably met through her brothers who were also professional footballers.

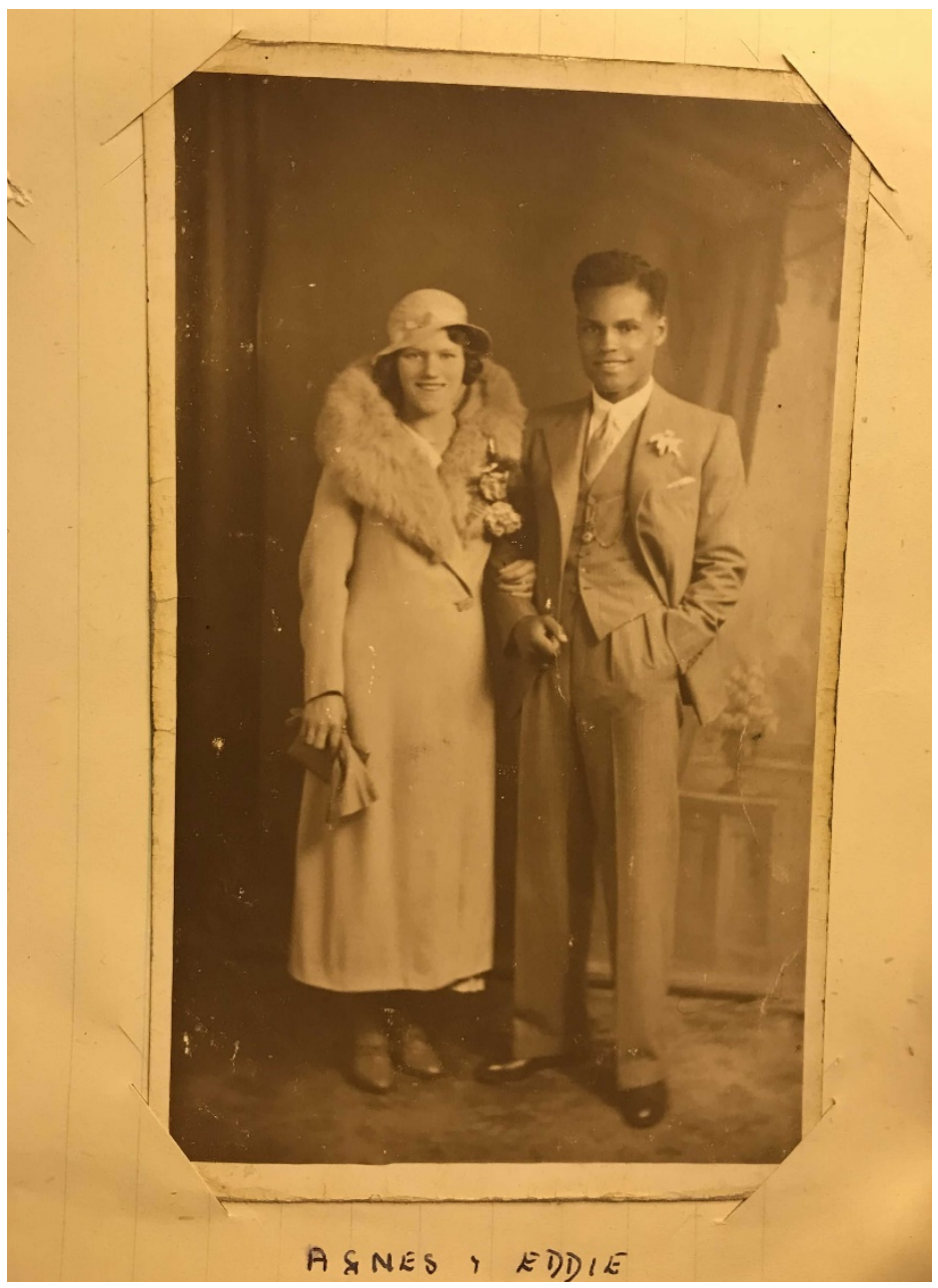

Agnes and Eddie Parris wedding photograph (courtesy of his nephew Graham Shaw)

This might have caused him some tension in the interwar atmosphere of fears around interracial sex. Yet, as Holland has argued, 'the mutuality of marriage, neighbourliness, friendship and work' facilitated racial integration. ${ }^{1}$ Parris' nephew recalls that the Shaws accepted Eddie completely and that the wider family socialized together. ${ }^{1}$ This does not mean that others were so understanding but it is not unreasonable to suggest that, whatever prejudices he may or may not have faced, Parris also lived a meaningful life that should not be considered only through the parameters of discrimination. He seemed to have married into a supportive family. As a professional footballer, he would have enjoyed some respect and fame and earned good wages. His job, of course made, him different to the majority of black Britons but it also stood him apart from most white Britons too. The evidence might not exist to make any certain judgements about Parris, or indeed nearly any working-class

\footnotetext{
${ }^{1}$ Holland, 'Social networks', p. 278. In 1949, fourteen years into their marriage, Eddie and Agnes had a son David. He died that same year.

${ }^{1}$ Email correspondence with Graham Shaw, 23 January 2018.
} 
person of colour, but to not try is to condemn such individuals to the dustbin of historical condescension.

\section{Parris the footballer}

Parris joined Second-Division Bradford Park Avenue aged seventeen after being spotted by playing for Chepstow Town in the Gloucestershire Northern League. He had been playing for Chepstow since he was sixteen, an achievement for any teenager given how physical play could be at such a level and perhaps an even greater one given how his colour might have made him the target of rough play and abuse from the crowd. ${ }^{1}$ Parris made his senior debut for Bradford in January 1929, just before his eighteenth birthday. He played for the club for six years, although he was not always in the first team, and it was while there that he won his one and only Welsh cap. Why he left for Bournemouth in the division below is unclear but there he was both a regular player and scorer. ${ }^{1}$ He then signed for Luton Town for a 'substantial fee' in 1937 but did not establish himself and joined Northampton before the war disrupted his career. ${ }^{1}$

Eddie Parris' Football League Career ${ }^{1}$

\begin{tabular}{lcccc}
\hline & & $\begin{array}{c}\text { League } \\
\text { appearances }\end{array}$ & Goals & Division \\
\hline Bradford Park Avenue & $1928-34$ & 132 & 38 & 2 \\
Bournemouth & $1934-36$ & 104 & 23 & $3(\mathrm{~S})$ \\
Luton Town & $1936-37$ & 7 & 2 & $3(\mathrm{~S})$ \\
Northampton Town & $1937-39$ & 25 & 7 & $3(\mathrm{~S})$ \\
\hline
\end{tabular}

When war broke out, normal professional football was suspended and Parris moved to Gloucester, some thirty miles from Chepstow where his parents and wife were living. ${ }^{1} \mathrm{He}$ had found employment with the Gloster Aircraft Company who manufactured military aircraft. This was presumably a reserved occupation but with no nearby Football League team, it also saw the end of his senior football career, despite only being 28 . The factory did, however, have its own team who Parris began playing for, whilst also turning out for Gloucester City in the Southern League. ${ }^{1}$ He went on to play for Bath City before joining Cheltenham Town of the Southern League in 1946. A year later, he became player-coach back at Gloucester in what seems to have been his last season as a player. ${ }^{1}$

Press reports suggest Parris was a player of some, although inconsistent, talent, whose play centred on speed, dribbling and ball control. In 1932, the Daily Mail called him 'not a little football genius'. ${ }^{1}$ A year later, the Daily Mirror reported that Everton were interested in

\footnotetext{
${ }^{1}$ Gloucestershire Echo, 1 October 1927. On local football see Martin Johnes, Soccer and Society: South Wales 1900-39 (Cardiff, 2002), ch. 3. For memories of racial abuse in interwar local football see Ian Pincombe, "Out of Rexville": G. F. Lovell and the south Wales confectionery industry, c.1830-1940' (Ph.D., University of Wales, 2000), p. 221.

${ }^{1}$ Leeds Mercury, 28 April 1934.

${ }^{1}$ Nottingham Journal, 18 February 1937.

${ }^{1}$ Gareth M. Davies \& Ian Garland, Who's Who of Welsh International Soccer Players (Wrexham, 1991), p. 158.

${ }^{1} 1939$ register: Tubulas cottage, Beachely Rd, Chepstow.

${ }^{1}$ Gloucestershire Echo, 23 November 1939, 25 November 1944, 22 February 1943.

${ }^{1}$ Sports Argus, 11 October 1947.
} 
signing him; it described him as 'a very speedy dribbler, Parris makes a speciality of 'selling the dummy,' which has greatly endeared him to the Park-avenue crowds'. ${ }^{1}$ In 1934, a match report said:

It was fitting, too, that Bradford's other goal was made by their other winger, Parris, the coloured player at outside left, who was another personality of the match.... It is surprising how often Parris has a hand in his side's scoring efforts. Sometimes he may do surprisingly weak things; there were occasions in this game when he lost the ball without a Preston man near to take it from him. But one never knows when Parris may show a thrilling a burst of speed and either score or make the running for a goal. ${ }^{1}$

Professional football was a relatively comfortable occupation that was not hard physical labour and could bring a degree of local fame and status. More importantly, the pay, while not equivalent to middle-class professional salaries, was good. The Football League enforced a maximum weekly wage of $£ 8$ from 1922, but this was notably more than most workers earned. In 1938, for example, skilled engineering workers were typically paid $£ 3$ 10 s, while engineering labourers received $£ 210$ s. $^{1}$ Moreover, compared with the income of those on National Assistance or unemployment benefit - something black workers often found themselves reliant on - players' wages represented a small fortune. In 1934-35, in the middle of a dispute over their employment in shipping, the League of Coloured Peoples estimated that 80 percent of black men in Cardiff had been unemployed for much of the year. To make things worse, the levels of assistance paid to unemployed black men were sometimes lowered because they were living communally or even thought to be accustomed to a lower standard of living. ${ }^{1}$

What Parris earned is unknown but it was probably much more than he would have done in any other industry where his colour would have curtailed his opportunities. Whilst at second-division Bradford, he may have received the maximum wage but after that his career was spent in the third division where few players would have earned the maximum and many considerably less. ${ }^{1}$ Lower division players had to be prepared to move around to find work and they often faced irregular employment, with contracts limited to a year and sometimes not renewed until after the summer break to save money. That Parris experienced such insecurities is evident in how he had three different clubs between 1936 and 1939. The practical impact of this on his life is demonstrated by the 1939 National Service Register which shows Parris resident in a Northampton boarding house, while his wife was living with his parents in Chepstow. Nor in the long term did football elevate Parris, and nearly every other professional player, out of the working class. After his retirement, he settled in Gloucester and found work in the British Nylon Spinners factory. When he died from lung cancer in 1971, his death certificate recorded his address as a semi-detached house on a working-class street. Yet such experiences were the norm for white footballers too and race alone can never be used to interpret black lives.

\footnotetext{
${ }^{1}$ Daily Mail, 15 February 1932.

${ }^{1}$ Daily Mirror, 4 October 1933.

${ }^{1}$ Leeds Mercury, 8 January 1934.

${ }^{1}$ Dave Russell, Football and the English (Preston, 1997), pp. 45-52, 92-95.

${ }^{1}$ Ramdin, Making of the Black Working Class, pp. 82-83.

${ }^{1}$ Matthew Taylor, 'Beyond the maximum wage: the earnings of football professionals in England, 1900-39', Soccer and Society, 2:3 (2001), 101-118, p. 105.
} 


\section{Black footballers}

Parris was one of a number of black players to feature in the Football League before 1939. Vasili's pioneering history of black footballers in Britain lists twenty players with nonEuropean heritage before the Second World War. ${ }^{1}$ But since there were no official records of race, there could be others who historians have missed. One of Vasili's examples was Andrew Watson, who played in the 1880s, but was only 'discovered' after Vasili noticed his colour in a team photograph. The likelihood of more black players is made stronger by the high turnover of labour in the football industry. There is evidence of clubs giving trials to players from the colonies and others playing just a few games after arriving in Britain to study or work in other industries. ${ }^{1}$ Identifying players of colour is made more difficult by the fact that the press did not always mention their ethnicity. One player absent from Vasili's survey was Willie Clarke, who had either a black mother or grandmother according to different modern researchers. He played for a number of English and Scottish Edwardian clubs, and, although some papers referred to him as 'dusky' or 'darkie', colour was not central to how newspapers portrayed him. For example, in 1909 the Leeds Mercury reported that Leeds City were interested in signing this 'brilliant outside right', but made no mention of his race. ${ }^{1}$

Between the wars, there was one other well-known black player in the Football League. Jack Leslie was the son of a Jamaican labourer and a very successful inside left with Plymouth Argyle from 1921 to 1935 who scored 137 goals in 401 appearances. Like Parris, he was often described in the press using racial epithets. For example, after Plymouth played in Bristol a local newspaper reported that 'Darkie Leslie was their best man - in the fact, the cleverest footballer on the field'. ${ }^{1}$ In 1925 the Sports Budget tried to make this something humorous with a cartoon that read 'This is 'Dusky' Leslie so called because he never does anything shady'. ${ }^{1}$ However, despite being highlighted or joked about, neither Parris' or Leslie's colour was ever turned into any kind of basis for discussion in such articles. When the two were likely to appear in the same match in 1929 one newspaper printed their pictures under the heading 'Coloured cup-tie rivals' but it made no comment beyond reporting the facts. ${ }^{1}$ Similarly, match reports might use colour to describe Parris but never went beyond employing this as a descriptive adjective. Nor was colour always used to describe him, particularly in papers where the readership would already know him. When he signed for Bournemouth in 1934, the local newspaper report was headed 'Welsh international signed' and only later in the main text was his colour referred to. ${ }^{1}$ Indeed, the language used to describe black players also seems to have become more muted over the period. Whereas Leslie was called a 'darkie' or 'dusky' with relative frequency in the 1920s, Parris, playing in the 1930s, was much less referred to as 'dusky' and seemingly not at all as a 'darkie'. ${ }^{1}$ This perhaps hints at newspapers becoming more conscious of racial tensions in a decade when

\footnotetext{
${ }^{1}$ Phil Vasili, Colouring over the White Line: The History of Black Footballers in Britain (Edinburgh, 2004).

${ }^{1}$ Pierre Lanfranchi \& Matthew Taylor, Moving with the Ball: The Migration of Professional Footballers (Oxford, 2001), p. 177. For a report of such a trial that claims other players from the colonies were joining clubs see Lancashire Evening Post, 14 November 1933.

${ }^{1}$ Leeds Mercury, 23 September 1909. Ian Hemmens, 'The dusky flier: William Gibb Clarke', City Gent, December 2014, 46-47.

${ }^{1}$ Western Daily Press, 6 April 1926.

${ }^{1}$ Sports Budget, 13 March 1925.

${ }^{1}$ Leeds Mercury, 25 January 1929.

${ }^{1}$ Western Gazette, 8 June 1934.

${ }^{1}$ For Parris being called a 'dusky inside left' see Lincolnshire Echo, 1 November 1930.
} 
economic problems and the rise of fascism in Europe were causing race to become a more sensitive topic. However, once again, interpreting an archival silence can only be conjecture.

The absence or muted use of colour in the reporting of Parris and Leslie certainly hides a more complex reaction to black players. Whatever the intention, using colour to describe people 'others' and racializes individuals, designating them as different. ${ }^{1}$ Colour marked Parris and Leslie out from the multitude and gave them a profile white players of similar ability did not have. Parris was sometimes highlighted in match previews or reports as a notable player or personality. When Northampton travelled to play Notts County in 1937, for example, he was the subject of a small article that called him a Welshman and 'one of the few coloured men to have appeared in English League football'. ${ }^{1}$ Thus such players became exotic curiosities rather than just another professional player. The first black professional player in the Football League was Arthur Warton. He moved to Britain from Ghana and became a goalkeeper with a number of clubs between 1885 and 1902. In 1936, one writer recounted seeing him play. In doing so, he revealed both the curiosity racial difference could engender and how even the 1930s press could respond to that with offensive racial language.

I was kicking a ball about on Carr Road Recreation Ground one Saturday afternoon, along with other more or less grimy youngsters, when news came to us that a nigger was playing a match on the adjoining football field. In those days the sight of a nigger, or what to-day we more politely call a coloured gentleman, was to us young lads as big a thrill as the annual visit of Sanger's Circus, and off we scampered to try and get a look at this player. ${ }^{1}$

The exotic draw of seeing someone of colour playing must have tempted other supporters too. In 1936, the press reported that Celtic were giving a reserve game to Bach Chi Khan from Calcutta. One paper thought the club's 'enterprise' was likely to be rewarded by an increased gate. ${ }^{1}$

The appeal of watching black players drew on ideas on racial superiority and that somehow, when put on display, those of colour were comic. This was most evident in minstrel groups, which, whether they featured white men blacked up or actual black actors, tended to portray those of colour as stupid and credulous. ${ }^{1}$ In 1913, in a report headed 'The Niggers War Dance' a writer in the Birmingham Daily Gazette recalled a black reserve goalkeeper at Bolton:

To see him standing up to a penalty was an education in gymnastics. Arms and legs were flung about as if he had not control over them; he pulled his face about in the most terrible manner, and, to add to the horror of it, introduced a few native war cries. An iron nerve was required to take a penalty coolly while he was in goal. ${ }^{1}$

\footnotetext{
${ }^{1}$ Habib, Black Lives in the English Archives, p. 12.

${ }^{1}$ Nottingham Journal, 10 December 1937.

${ }^{1}$ Nelson Leader, 5 July 1936. For his life see Phil Vasili, The First Black Footballer: Arthur Wharton, 1865-1910 (London, 1998).

${ }^{1}$ Hartlepool Northern Daily Mail, 27 August 1936.

${ }^{1}$ On minstrels see Bourne, Black in the British Frame and Michael Pickering, 'The Blackface clown', in Gretchen Holbrook Gerzina (ed), Black Victorians, Black Victoriana (New Brunswick, 2003), pp. 159-74. A touring team of black South Africans had similarly drawn intrigued crowds in 1899. Chris Bolsmann, 'The 1899 Orange Free State Football Team of Europe: 'Race', Imperial Loyalty and Sports Spectacle'. International Journal of the History of Sport, 28: 1 (2011), 81-97.

${ }^{1}$ Birmingham Daily Gazette, 28 January 1913. The memory was probably referring to Wharton and confused his club. Wharton played in Lancashire for Stalybridge, Ashton and Stockport,
} 
In a similar vein of 'comic' spectacle were matches between white and blacked up teams. In 1898, for example, a 'niggers' football match' in Ancaster was reported as 'providing a large amount of fun and amusement for the spectator, if not a large amount of scientific football'. 1 In 1907, the Stratton Minstrel Group even played a team of 'Suffragettes', after both took part in a 'grand fancy procession' to the field. ${ }^{1}$ Such 'humour' became less common after the First World War but it did not disappear and it was always underpinned by a blunt sense of racial superiority. In 1922, the Burnley News, published a story about an attempt to set up a 'team of all the nations'. It claimed 'some of these blighted foreigners really could play the game'. It went on that the 'nigger' at outside right was 'about the fastest fellow I've ever seen with a ball'. However, he mixed football with music, taking a banjo with him everywhere. The British players in the team hated this 'coal black coon', thought he smelt and ended up breaking both his nose and instrument. ${ }^{1}$

What such attitudes meant for the reception of the few black professional footballers is unclear since press reporting of crowd behaviour was limited. Football was an emotive sport where fans were far from passive. It was not unusual for supporters to 'barrack' players, usually when they were not performing to the levels expected. This might involve colourful language and it reflected wider social norms where workers were expected to maintain standards in their own occupations. ${ }^{1}$ Banter and humour were also part of working life and physical characteristics were often used to refer to workmates. It is thus surely not unreasonable to think that Parris must have experienced not just racial banter and labelling but also a degree of racial abuse from crowds, at least if his performances slipped or he annoyed opposing fans. No examples have been uncovered in the press but reporters would only have been aware of cases that led to complaints or that they could actually see or hear. Any racial attack by an individual or small group would have probably escaped their attention. Moreover, there is also the possibility that reporters would have chosen not to report it, perhaps for fear of raising awkward questions around race for football and wider society.

The challenges of understanding the extent of any racial abuse within football is evident in the case of other black footballers. In 1933, a report of Burnley $v$. Plymouth made no mention of Leslie's colour but complimented him on how he rallied his team, called him 'indefatigable' and the 'brainy man in the side', and claimed that everything he did had purpose behind it. ${ }^{1}$ Later the same week the newspaper published two letters from fans who had seen the game, highlighting that his colour had not gone unnoticed and suggesting it was thought by fans to be something worth joking about. One was simply remarking on the fact that Plymouth had another player called Black who was white whereas the 'black chap' in their team was not. The other was a claim that Plymouth was like a game of snooker because

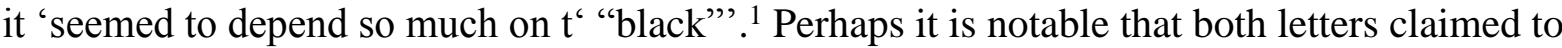
have overheard the remark rather than thought of themselves. This might be a sign that it was acceptable to laugh at racial humour but perhaps best if left to someone else to make the joke. Vasili has argued that Jack Leslie experienced 'consistent abuse' but that newspapers either ignored it or referred to it in abstract terms that avoided race. ${ }^{1}$ His daughter meanwhile later said that her father had 'a lot of disappointments because of his colour'. ${ }^{1}$ Yet Leslie himself

\footnotetext{
${ }^{1}$ Grantham Journal, 8 October 1898.

${ }^{1}$ Swindon Advertiser and North Wilts Chronicle, 24 May 1907.

${ }^{1}$ Sydney Horler, 'The team of all nations', Burnley News, 25 February 1922.

${ }^{1}$ Martin Johnes, 'Hooligans and barrackers: Crowd disorder and soccer in south Wales, c.1906-39', Soccer and Society, 1, 2 (2000), 19-35.

${ }^{1}$ Burnley Express, 20 September 1933

${ }^{1}$ Burnley Express, 23 September 1933.
} 
told a writer in the 1980s that the only time in his career that he had faced prejudice was when it came to his chance of playing for England. ${ }^{1}$

Another example where the evidence around racial attitudes of football crowds is uncertain is Walter Tull. He played for Tottenham Hotspur and Northampton Town before 1914 and is now the most celebrated early black footballer. Vasili's study of Tull only produces one example of a crowd racially abusing him. ${ }^{1}$ In a match report with the subheading 'Football and the Colour Prejudice', a reporter recorded that

Tull has much to contend against on account of his colour. His tactics were absolutely beyond reproach, but he became the butt of the ignorant partisan. Once, he 'floored' Annan with a perfectly fair shoulder charge, a section of the spectators made a cowardly attack upon him in language lower than Billingsgate.

But it is notable that the reporter noted how the 'Bristol hooligans' were 'but a few ... in a crowd of nearly twenty thousand'. He concluded 'Tull is so clean in mind and method as to be a model for all white men who play football, whether they be amateur or professional. In point of ability, if not in actual achievement, Tull was the best forward on the field'. ${ }^{1}$ Other newspapers took different approaches to the incident. A brief report in the Derby Daily Telegraph and a much longer one in the Athletic News make no mention of it at all. It did make the Illustrated Police News but that paper attributed the incident to Tull's fair shoulder charge and made no mention of his colour. ${ }^{1}$ The absence of press reports of racial abuse towards Parris should thus not be taken as an indication that no such abuse took place. But there is nothing to suggest that it was common and, as with the above case, anything that did happen might have been limited to the actions of a few fans and disapproved of by others.

There is, however, direct comment in the press that Parris was popular with crowds. ${ }^{1}$ Fast players able to get past defenders were always popular but his colour may have added to his appeal since it made him stand out. Cricket and boxing also had black athletes who were popular with white audiences and there were also popular black musicians and entertainers. ${ }^{1}$ Moreover, Hill has argued that the popularity of Learie Constantine, a 1930s West Indian cricketer who played for Nelson, owed much to how people in Lancashire related to how he had, through 'ambition, hard work and dedication', succeeded and got on in life. Thus, despite his colour, Hill argues that in Constantine locals 'were able to perceive someone who seemed like themselves'. ${ }^{1}$

With the majority of white Britons not knowing anyone black, interacting with black stars, even if only indirectly, helped people develop and think through their attitudes to people of colour. In his 1940s study of race, Kenneth Little argued that contact with black

\footnotetext{
${ }^{1}$ Phil Vasili, 'Leslie, John Francis [Jack] (1901-1988)', Oxford Dictionary of National Biography, 2015.

${ }^{1}$ Inside Out - South West, BBC, 27 September 2004.

${ }^{1}$ Brian Woolnough, Black Magic: England's Black Footballers (London, 1983), p. 4.

${ }^{1}$ Phil Vasili, 'Walter Daniel Tull, 1888-1918: soldier, footballer, Black', Race \& Class, 38: 2 (1996), 51-69.

${ }^{1}$ London Daily News, 4 October 1909.

${ }^{1}$ Derby Daily Telegraph, 2 October 1909. Athletic News, 4 October 1909. Illustrated Police News, 9 October 1909.

${ }^{1}$ For example: Leeds Mercury, 28 April 1934. 1

${ }^{1}$ Jeff Hill, 'Connie' - Local hero, national icon: sport, race and politics in the legend of Learie Constantine', Sports Historian, 22:1 (2002), 79-99, pp. 87-8.
} 
people playing sport and participating successfully in other 'English social customs' created 'a very favourable impression' which could lead to positive views of black population in general. ${ }^{1}$ Key to their popularity was not just how they excelled in an important cultural space but also how this did not represent any kind of unsettling or threatening idea around race. Black sportsmen and entertainers were exceptions, operating in realms where most white men could not hope to make a career. This also limited the potential emancipatory message that their achievements might represent. Indeed, black sporting successes might also have reinforced the ideas of racial difference that underpinned racism by contributing to the myth of 'primordial' black bodies, physically able but lacking in cognitive abilities. ${ }^{1}$

Moreover, the emancipation sport could offer was further limited by how black athletes were expected to behave in ways that did nothing to challenge racial hierarchies. Before the First World War, the non-submissive demeanour and perceived arrogance of the AfricanAmerican boxer Jack Johnson had contributed to government interventions to stop him fighting in the UK and to the emergence of a formal colour in the sport that insisted British champions must have two white parents. ${ }^{1}$ Parris, in contrast, was described by one newspaper as 'a quiet, unassuming young man' who was 'popular wherever he goes, particularly on London grounds'. ${ }^{1}$ It is difficult not to conclude that this popularity must have owed something to how Parris did not represent any kind of threat to the white majority.

The complexities and contradictions of the impact of black successes in popular culture is evident in the fields of music and entertainment. Bressey and Romain have shown how 1920s British fan letters sent to Florence Mills, an African-American singer, reveal how black public figures helped people think through race but in quite different ways. While some saw in her an inspirational challenge to class, gender, and racial barriers, others retained a profound sense of racial difference despite their admiration for her achievements. ${ }^{1}$ There were similar contradictions around Paul Robeson who was one of the biggest box-office draws of the age. A 1939 Mass Observation investigation found that British people used him as a way of exploring racial difference. The conclusions they drew from seeing Robeson's films and hearing him sing were, however, different. For some, he was an exception to the rule of black inferiority but to others he was an example of what black people could achieve and contribute if they were given a chance, although they might think this only applied in certain cultural spheres. ${ }^{1}$

This all suggests that Parris' impact on the racial views of the fans who saw him play could have been contradictory, sometimes positive, sometimes negative, sometimes irrelevant. Indeed, his own day-to-day experiences with fans were also probably mixed. Hill has argued that fame protected Constantine from the prejudices and discriminations that working-class black people routinely faced but, in both London and in his adopted hometown, he was still subject to a degree of discrimination based on colour. ${ }^{1}$ Parris, no doubt, experienced a similar situation.

It was not just from supporters that Parris might have experienced prejudice within football. The contemporary racial attitudes of whites often meant a reluctance for close

\footnotetext{
${ }^{1}$ Little, Negroes in Britain, pp. 243-6.

${ }^{1}$ Ben Carrington, Race, Sport and Politics: The Sporting Black Diaspora (London, 2010).

${ }^{1}$ Theresa Runstedtler, Jack Johnson, rebel sojourner: boxing in the shadow of the global color line (Berkley, 2012). On racism in British boxing more broadly see Martin Johnes and Matthew Taylor, 'Boxing, race and British identity, 1945-62', Historical Journal (2020), 1-29.

${ }^{1}$ Belfast Telegraph, 3 December 1931.

${ }^{1}$ Caroline Bressey and Gemma Romain, 'Staging race: Florence Mills, celebrity, identity and performance in 1920s Britain', Women's History Review, 28, 3 (2018), 380-95.

${ }^{1}$ Kushner, We Europeans, pp. 124-6.

${ }^{1}$ Hill, 'Connie', pp. 90-91.
} 
physical contact with the black population. This must have structured the reactions of least some opponents and teammates. There is evidence from amateur sport of a reluctance to play against black men. A Cardiff cricket side, largely made up of West Indians, always had to travel far out of the docks district where they lived to get a game. Even then, their appearance would be greeted with a degree of surprise and shock. A 1930s multiracial football team known as the Cardiff All Blacks chose not to enter the local league and instead played charity matches which presumably offered them a degree of protection from routine slights. ${ }^{1}$ Jack Leslie later recalled how he was the subject of regular abuse from other players, although he qualified how he regarded this. In 1978, he told a journalist:

"Here darkie," they'd shout, 'I'm gonna break your leg." "No, you won't, whitey, 'cause I'm harder," I used to shout back.

"There was nothing wicked about it. They were just trying to get under your skin. They'd have been on at me the same if I'd had a ginger-nob. Anything to rattle you. It was a hard game, then as now."

Parris probably faced similar issues, not just with opponents but also teammates who had to work in close quarters with someone of colour and also bathe with him afterwards. Given the depth of some racial attitudes, it is difficult not to conclude that at least some teammates must have at least initially baulked at this experience. As late as the $1960 \mathrm{~s}$, one survey was told by a black cricketer that whites did not want to use the bath after he had used it. ${ }^{1}$

But football teams were also built on camaraderie. Thus, after initial shock, the shared experience and team spirit probably brought Leslie and Parris closer to their workmates than might have been the case in other industries. Leslie was given the captainship of Plymouth and thus a position of authority over his white teammates. This might also explain why Walter Tull was able to become an officer during the First World War at a time when such positions were supposed to be limited to those of European descent. Tull was a member of the Footballers' Battalion where, according to Vasili, there was 'an environment of self- and mutual respect. ... The field of play is a great leveller. Strengths and weaknesses are exposed to view to be exploited. It is a place where cultural myths can be exorcised' ${ }^{1}$ There is a degree of speculation here, as there is in all analysis of what life was like for black footballers, but it is not unreasonable to conclude that it was a profession that gave them a status that would otherwise have been difficult to obtain. However, racial prejudices were deep enough in society that famous black footballers probably still faced discrimination, even if the archives are silent on how.

\section{Parris the International}

In 1933, a Daily Mirror article by the Chelsea manager on foreign players in British football discussed Leslie and Parris, who it called 'the dusky outside left of Bradford'. The article did not appear to be implying they were not British but their inclusion was nonetheless a sign of how black men in Britain were regarded as not quite the same as everyone else. ${ }^{1}$ Interest in the topic seems to have been generated by Frank Soo making his debut for Stoke City. Soo was the son of a white mother and Chinese laundry owner and went on to forge a successful career. Like Parris and Leslie, the press often made reference to his ethnicity but did not make it the subject of debate or discussion. ${ }^{1}$ His professional debut in 1933 also led the Daily

\footnotetext{
${ }^{1}$ Little, Negroes in Britain, pp. 42, 105, 140. Johnes, Soccer and Society, p. 96.

${ }^{1}$ Daily Mail, 8 December 1978.

${ }^{1}$ W. W. Daniel, Racial Discrimination in England (London, 1968), p. 47.

${ }^{1}$ Vasili, 'Walter Daniel Tull', p. 64.

${ }^{1}$ Daily Mirror, 4 November 1933.
} 
Mail to run an article on the 'Coloured stars of football'. It said it did not know what colour Soo's skin was but that he was 'as English in thought and manner as the next man' and 'British by birth'. It concluded that 'The doors of sport ... are open to everyone.' later, the Sports Argus ran a feature on the same theme, which claimed that Leslie and Parris were 'assumed to be foreigners' on account of their 'swarthy skins'. It asserted Soo had won his way into the Stoke team on merit and that 'it should not matter the nationality of any man providing he plays the game earnestly and intelligently'. But it also stressed that Soo was born in the UK and that his Chinese father had become a 'naturalised Britisher'. Even then, the report contradicted itself by saying his popularity at Stoke 'shows that British sportsmen don't worry about nationality so long as a man behaves himself like a sportsman'. ${ }^{1}$ Thus the press asserted that whiteness and Britishness could not be equated but still fell into doing exactly that. If Parris, Leslie or Soo read any of these articles, it must have made them feel outsiders in the land of their birth.

The whiteness of Britain, or at least England, may have even been officially sanctioned in 1925 when it appeared that Jack Leslie had been selected as a reserve for an England match. In later years, he told the story that he had been chosen only for this to be rescinded when the FA discovered he was black. ${ }^{1}$ The story was a little more complicated. England teams were picked by a selection committee of fourteen administrators who voted on the team, showing little consistency but much experimentation and confusion. ${ }^{1}$ The selectors were picking large numbers of players who they appeared to know little about and it is not impossible that Leslie was chosen without any knowledge of his colour. One paper regarded his selection as a 'surprise', while another called the whole team 'experimental'. ${ }^{1}$ However, after his selection was announced in the press the story disappeared and Leslie never joined up with the team. The Daily Herald sought further information and was informed by the FA that Leslie had never been selected. Yet the Press Association told the paper that its announcement of his selection had come from the Football Association. ${ }^{1}$ The Plymouth press had initially welcomed his selection but then dropped the story. One local reporter did, however, write:

My readers may be expecting from me a comment upon the Argyle Club's announcement that Jack Leslie was not chosen as reserve forward for England. Unfortunately my pen is under a ban in this matter: but I may say that a mistake was made in London and transmitted to me. Anyway, Leslie was at that time playing quite well enough to be chosen. ${ }^{1}$

Clearly some people at the time felt something untoward had occurred. Yet it is notable that nowhere in the discussion was his colour mentioned. The selection of a black man had not been not the cause of celebration and if it was thought that he had been deselected because of his colour, as Leslie believed, then this was not a matter for public discussion either. Nonetheless, eight years later, the Daily Mail said of Leslie, 'Had he been white he would

\footnotetext{
${ }^{1}$ Susan Gardiner, The Wanderer: The Story of Frank Soo (Stowmarket, 2016).

${ }^{1}$ Daily Mail, 2 November 1933.

${ }^{1}$ Sports Argus, 4 November 1933.

${ }^{1}$ Daily Mail, 8 December 1978.

${ }^{1}$ Brian James, England v Scotland (London, 1970), pp. 117-8, 119.

${ }^{1}$ Northern Whig \& Belfast Post, 24 October 1925. Birmingham Gazette, 6 October 1925.

${ }^{1}$ Daily Herald, 28 October 1925.

${ }^{1}$ Football Herald, 6 and 31 October 1925.
} 
have been a certain English international. ${ }^{\text {'1 }}$ It made no further comment. Racial discrimination was perhaps simply a matter of fact.

In 1931, Eddie Parris was selected for Wales against Ireland. One newspaper then called him 'one of the best wing-men in the Second Division' but in reality his selection owed much to tensions within football. ${ }^{1}$ At the time, Football League clubs were often refusing to release non-English players for Saturday internationals because of their own fixtures. The result was selectors had to scour the lower leagues for players. On the day the Welsh team was scheduled to travel to Belfast, the press reported that Wales was still two players short. ${ }^{1}$ Parris ended up being one of four new caps in a team that included a player from amateur Oswestry Town. Wales lost 4-0 and one report concluded that Parris was 'not up to international standard'. ${ }^{1}$

Parris was not the first black player to gain an international cap for a British nation. That milestone belonged to Andrew Watson, the mixed-race son of a wealthy plantation manager from Guyana who moved to the UK as a child, going on to study at Glasgow University. He gained three caps for Scotland in the 1880s on the basis of his residency. By 1931, Watson appears to have been forgotten and there was limited interest in the novelty of Parris' selection. The Daily Telegraph reported that Parris was the first 'coloured man' to be capped by one of the home countries, although it thought he had been born in Barbados. ${ }^{1}$ The Sunderland Echo noted 'Rarely, if ever, has a coloured player appeared in an international Soccer match, and much interest was aroused by the announcement'. ${ }^{1}$ Yet most newspapers showed no interest in the colour dimension and there appears to have been no widespread sense in the public sphere that anything significant had happened. In Wales, interest was more about his locality than his colour. The South Wales Argus, which covered his native Newport and Chepstow, printed his picture and called Parris 'a clever coloured outside left, of Bradford, who is a native of Chepstow'. Another report in the same paper was headed 'Pwllmeyric Player in Welsh Team' and made no mention of his colour. ${ }^{1}$ The Yorkshire connection meant the Leeds Mercury headlined its report 'Distinction for Parris - Bradford forward to play for Wales on Saturday' but again it made no mention of his colour. ${ }^{1}$ If anyone thought Parris' cap was a sign of racial inclusion in Welsh or British identity the point was not made in public.

Whether Parris himself thought his selection symbolic is also lost. So, too, is his view of his nationality. Welshness was often an elusive identity. There was no discussion of it in Little's contemporary analysis of Cardiff's black population and he even subtitled his book 'a study of racial relations in English society'. ${ }^{1}$ Parris' parents were not Welsh and he had grown up on the edge of a border county whose own legal position as part of Wales was

\footnotetext{
${ }^{1}$ Daily Mail, 2 November 1933.

${ }_{1}^{1}$ Sunderland Echo, 3 December 1931.

${ }^{1}$ Evening News, 3 December 1931.

${ }^{1}$ The Scotsman, 7 December 1931.

${ }^{1}$ Daily Telegraph, 3 December 1931.

${ }^{1}$ Sunderland Echo, 3 December 1931.

${ }^{1}$ South Wales Argus, 2 and 3 December 1931.

${ }^{1}$ Leeds Mercury, 2 December 1931.

${ }^{1}$ Colonial subjects in Britain were comfortable with the label British but used the label English to refer to 'natives'. Anne Spry Rush, 'Imperial identity in colonial minds: Harold Moody and the League of Coloured Peoples, 1931-50', Twentieth Century British History, 13:4 (2002), 356-83, p. 362. David Killingray, “A good West Indian, a good African, and, in short, a good Britisher': black and British in a colour-conscious Empire, 1760-1950', Journal of Imperial \& Commonwealth History, 36:3 (2008), 363-81.
} 
ambiguous. It was also an area where the Welsh language, the most important cultural distinction to England, was weak and, of course, football had taken him to live across the border aged seventeen. ${ }^{1}$ But sport was also an important inclusionary tool in a nation that had experienced extensive immigration from England and which relied on symbols and culture to assert its nationhood in the absence of the apparatus of a state. ${ }^{1}$ Thus football may well have helped Parris feel Welsh in an environment where there was little else to do that. Yet, for whatever reason, he was never capped again. The dispute over the release of players eased and the following season Wales won the home championship with a very different side to the one that Parris had played in.

\section{Conclusion}

At a time of economic depression, football gave Eddie Parris a career, earnings and a public status that nearly all black working-class men simply did not have. But it also exposed him to white audiences and brought him into close physical contact with other white workers. The archives are silent on how their engrained prejudices and assumptions impacted on Parris but it is surely impossible that they had no effect. Nonetheless, figures like Parris still demonstrate that white Britons were willing to live with, work with and celebrate people of colour.

Yet such figures remained 'different'. The few historical records created by Parris' life and career might be free of evidence of racism but they are not free of race. Newspapers show how his colour clearly marked him out, even if there was rarely any comment on the significance of this. The fact that reporters never asked him about this is not necessarily evidence of a desire to suppress racial consideration - virtually no players beyond the game's biggest stars were interviewed by papers - but nor did reporters often make their own comment and it is thus difficult not to think that the press was avoiding turning race into a public issue in sport. Since black Britons raised awkward questions about what it meant to be British it was easier just to avoid the subject. Yet that does not mean there was no significance to black sportsmen and the few sources that did discuss this welcomed it, even if they revealed how embedded a sense of racial otherness was in doing so. Ultimately, racial attitudes in Britain were complex and contradictory. Racism co-existed with integration. Interaction with and appreciation of black individuals encouraged white people to adopt more positive racial attitudes without ever changing how deep beliefs in racial difference ran.

The relative absence of colour in archival sources has led the British historiography of race to concentrate too much on the reactions of white Britons and not enough on black experiences. With some notable exceptions, this has created an analytical emphasis on racism and discrimination rather than the agency of black men and women to resist and overcome prejudices and to live meaningful lives. Little argued in his 1940s study of race that people reacted in different ways to prejudice according to their personality and background. ${ }^{1}$ Parris' background but not his personality can be established from the archives. There does not seem to be any historical record of anything he ever said. Eddie Parris the man rather than Eddie Parris the footballer is only visible in the memories of those who knew him. His nephew, who met him on a number occasions as a boy, recalls 'a large, warm, happy man who always had a smile and a friendly word for me', taught him how to play cricket in the back garden and was very much part of the family. ${ }^{1}$ Parris was a son, a

\footnotetext{
${ }^{1}$ Chris Williams, 'Who talks of my nation?', in Chris Williams and Andy Croll (eds), The Gwent County History, vol. 5: The Twentieth Century (Cardiff, 2013), 342-62.

${ }^{1}$ Martin Johnes, A History of Sport in Wales (Cardiff, 2005).

${ }^{1}$ Little, Negroes in Britain, p. 261.

${ }^{1}$ Email correspondence with Graham Shaw, 23 January 2018.
} 
husband, a father, a brother, an uncle and a friend. Little might be now known about that side of his life but it is as significant as his position as a black footballer. Archival silences might encourage historians to use race as the sole lens through which to consider black Britons but to do so is to judge them just as victims or survivors rather than the more rounded, richer individuals they actually were. 